\title{
Correction to: Gulf of Porto: Calanche of Piana, Gulf of Girolata, Scandola Reserve, France
}

\author{
Correction to: \\ Chapter 73 in: V. Claudino-Sales, Coastal World \\ Heritage Sites, Coastal Research Library 28, \\ https://doi.org/10.1007/978-94-024-1528-5_73
}

The names of two authors in the reference section of this chapter, namely Martin D and Balazs S, were published incorrectly. The authors' names have been corrected to read as Danišík M and Székely B. 